\title{
Access to the ICT Network as a Public Task of Local Government
}

\author{
KATARZYNA CHAŁUBIŃSKA-JENTKIEWICZ
}

\begin{abstract}
The purpose of this paper is to describe the duties of local government units under the legal conditions related to access to the ICT network in Poland. Establishing public-private partnerships in the telecommunications sector, which is a field closely tied with cybersecurity, seems inevitable and necessary. The need to cooperate is the consequence of the development of information and communication technologies, which leads to their increasingly wide application in all aspects of social life. The tasks of local government involving network access have become key to the process of broadband network development. That is why public funding becomes particularly important in its absence, justified by the need to provide conditions for internet access as a human right. This has become especially topical as we face the challenges of COVID-19.
\end{abstract}

Keywords: • access to ICT network • telecommunications access • cybersecurity $\bullet$ local government $\bullet$ human rights

CoRresPondence ADDREss: Katarzyna Chałubińska-Jentkiewicz, Ph.D., Associate Professor, War Studies University, Department of Cybersecurity Law and New Technologies Law, Law Institute, Aleja Generała Antoniego Chruściela „Montera” 103, 00-910 Warszaw, Poland, email: k.jentkiewicz@akademia.mil.pl.

https://doi.org/10.4335/19.1.175-195(2021)

ISSN 1581-5374 Print/1855-363X Online C 2021 Lex localis

Available online at http://journal.lex-localis.press. 
Today's society is often called the information society, the third wave society, or the cybersociety. It may be assumed that the information society is one which has specific technical and legal means. First and foremost, however, it has the knowledge to take advantage of these means. That is why we often speak about the knowledge-based society, and even the network society. For some time now, the concept of the security of the State is strongly tied with its information security, or network security. It should be stressed that information security has always been present as an important element in the State policies of security and defence, combining the legal procedures and instruments for protecting data, information, and systems. Information security is an essential part of proper scientific and technical progress, and, as such, it defines the needs for information protection, not only in the context of utility, but also to counteract the threats connected with its processing. In this era of global digitalisation, the development of social media, ubiquitous mailings' and e-mails' being sent to multiple recipients collected into databases, access to telecommunications and ICT networks becomes extremely important. This is the most important and main aim of this work to show that the access to the internet is the public task. Especially at the local level.

An open and free global cyberspace allows cultural and experiential exchange across countries, societies, and individuals, facilitating interaction and information sharing, leading to the spread of knowledge, experience, and technology. It could be said that, in a sense, the fact that this field is not regulated allows technology exchange, and, as a result, favours innovation development. On the other hand, the influence of States on the regulation of telecommunications activities is not limited to providing the organisational framework for the development of the State's information system, facilitating access to a fast internet, developing e-services and resources, and popularising digital competences among citizens. By using the instrumental function of law (legal rules constitute the key instrument of exerting influence on the social and economic reality), the State attempts to standardise telecommunications activities in the regulatory aspect, as well as in terms of order and rationing. The scope of legal regulations can be in conflict with the values of the information society, and the democratic rule of law, by introducing restrictions on the right to obtain and disseminate information. Instead of actions which should enlighten a new cultural policy, thus favouring the emergence of a new information-centred policy based on the modern values of a network society, restrictions on freedom of speech and access to information might appear. This is especially true of the attempts to apply to the new circumstances and technologies regulations typical of traditional mass media, which are anachronistic in the age of digitalisation, at least in some fields. Due to the specificities of the ICT network and the multifunctional nature of increasingly inexpensive and progressively enhanced mobile devices (in accordance with Moore's law) such a transfer of regulations could be seen as overly optimistic, as communication processes are the 
characteristic feature of social development. It is also these processes which are the mainstay of security and public order. Communication is a social process, which means that it involves a specific relationship. Such a relationship, in the case of public communication, acquires an institutional, public, and group-based nature, but also more and more often becomes a process centred on the individual and the individual's rights, due to the increasing personalisation of the message. The internet, which is based on the ICT network, is not only the new mass medium, but also a means to further the development of the traditional media - radio, television and press. And it is a place of economic activity, education, and all kinds of information exchange. Digital processes led to the emergence of what is known as the digital democracy, which also responds to the challenges related to the needs of living in the digital reality, something particularly noticeable during the COVID-19 pandemic (cf. on the role of public administration in an epidemic, see Karpiuk, Kostrubiec, 2018, pp. 69-73).

The subject of these primary activities is social participation in exercising public authority by engaging in a wider-than-ever public debate, including in the local sense. The tasks of a digital democracy and their implementation in virtual space remain open, and require constant enhancement, as information and access to it become a kind of public good, and a good inherently tied with the functioning of the individual. The necessary condition for maintaining and developing this good is not only the universal and innovative management of content published using the new media, but first and foremost the guaranteeing of the right of access to the ICT network, understood as the right of access to the internet, which is a human right. This is a public duty carried out primarily at the level of local governments, aimed at satisfying the needs of individuals at the local level, which is the closest to individual citizens.

\section{2}

\section{Methodology}

These considerations are largely analytical in nature, and are mainly based on the new regulations connected with the legal instruments supporting the development and access to the broadband internet. One of the key legal changes was the introduction of the definition of "public technical infrastructure" into the Polish legal system, for the purposes of explaining the application of regulations in terms of the placement of small-area wireless access points in the public space. This definition comes from Article 57 (4) of the European Electronic Communications Code (Directive (EU) 2018/1972 of the European Parliament and of the Council of 11 December 2018, establishing the European Electronic Communications Code, OJ L 321, 17.12.2018, p. 36-214) (hereinafter referred to as the Code). In accordance with this Article, "Member States shall, by applying, where relevant, the procedures adopted in accordance with Directive 2014/61/EU (DIRECTIVE 2014/61/EU of the European Parliament and of the Council of 15 May 2014 on measures to reduce the cost of deploying high-speed electronic communications 
networks, OJ L 155, 23.5.2014, pp. 1-14 ), ensure that operators have the right to access any physical infrastructure controlled by national, regional or local public authorities, which is technically suitable to host small-area wireless access points or which is necessary to connect such access points to a backbone network, including street furniture, such as light poles, street signs, traffic lights, billboards, bus and tramway stops and metro stations. Public authorities shall meet all reasonable requests for access on fair, reasonable, transparent and nondiscriminatory terms and conditions, which shall be made public at a single information point".

Public technical infrastructure was defined as "technical infrastructure owned or managed by a regional or local authority, or a national or local government organisational unit which is technically capable of having small-area wireless access points placed inside or on it, or necessary to connect such points into a telecommunications network, such as light poles, supporting structures of street signs, supporting structures of traffic lights, supporting structures of traffic safety devices, billboards, as well as railway, bus, and tramway stops and railway and metro stations." This definition provides a forum for discussion in the context of the tasks of local government units in the field of ICT access. We should differentiate telecommunications access from ICT access. The former is regulated by the provisions of telecommunications law, which implement the telecom regulations applicable in the EU, and represent the rule according to which telecommunications enterprises must operate, and which involves the use of telecommunications devices, related facilities, or services provided by another telecommunications enterprise, under specific conditions, for the provision of telecommunications services, including using them to provide services by electronic means or broadcasting services, which involve particularly:

a) access to network elements and associated facilities, including by connecting devices using stationary and non-stationary measures, including access to a local loop exchange and devices and services necessary to provide services in a local loop exchange.

b) access to telecommunications buildings and infrastructure

c) access to the appropriate software systems, including operational support systems

d) access to number translation or systems providing similar functions

e) access to telecommunications networks, including for the purposes of roaming

f) access to conditional access systems

g) access to virtual network services

h) access to information systems or databases for the purposes of preparing and submitting orders, providing services, carrying out maintenance, eliminating failures, processing complaints, and invoicing. 
Yet another type of access is entry to technical infrastructure provided by bodies to telecommunications enterprises and other entities. This kind of access is discussed in this paper, and is defined as ICT access. Both types of access arise from fundamental rights, particularly the right to obtain and disseminate information, i.e. the right to communicate.

As a consequence, the primary research method used in this paper is the legaldogmatic method. It is used to conduct an analysis and an assessment of the legal regulations pertaining to the activities of local government units in the field of telecommunications, as well as case law, including in particular that of the Polish Constitutional Tribunal. The secondary research method used in this paper is the theoretical-legal method, which is employed to evaluate access to the ICT network as a fundamental human right.

\section{Literature overview}

Considering the subject matter of this paper, it should be emphasised that there is no legal definition of public tasks in Polish law. However, such definitions are postulated in numerous academic papers. These include such papers as Kocowski 2006, Lang 1997, and Zimmermann 2008. At the same time, there are no major studies in the literature directly related to the subject matter of local government tasks in terms of telecommunications access (Kasina 2019). Instead, they discuss general tasks connected with the activities of local governments in the field of telecommunications (see Karpiuk 2019, Karpiuk, Position ... 2019, Babis FlagaGieruszyńska 2011, Dobkowski 2004, Galewska 2015, and Dziomdziora 2016, Czuryk, 2019). References which involve comments addressing specific Articles were particularly helpful (see Szydło, Grossmann, Knopkiewicz, Sebzda-Załuska, Wilczewski, Rogalski 2013). However, as articles important for this analysis have been amended in the Act on assistance in the construction of broadband infrastructure, there is currently no extended analysis of this subject in the literature. However, references to definitions and comments in the field of Telecommunications Law proved relevant (Piątek 2004).

\section{$4 \quad$ Research}

\subsection{Internet access as a fundamental human right}

While some States and international organisations are considering declaring access to the internet as a fundamental and universal human right, a number of governments are also thinking about stricter content control and the right to block the technical means of transmission. According to a survey conducted by the BBC World Service, which involved 27,000 adults in 26 countries, nearly "four in five people around the world believed access to the internet was a fundamental right." In this context, it is important to return to one of the most important rules declared during the World Summit on the Information Society (Geneva 2003 - Tunisia 
2005). Participants in this conference declared a joint desire and obligation to build a shared information society, where everybody would have the right to access, use and share information and knowledge, thanks to which individuals, communities and nations would be able to fully realise their potential in promoting their sustainable development and enhancing their quality of life, based on the objectives and rules of the Charter of the United Nations, and with full observance and upholding of the Universal Declaration of Human Rights. In accordance with recital 214 of the European Electronic Communications Code, "a fundamental requirement of universal service is to ensure that all consumers have access at an affordable price to an available adequate broadband internet access and voice communications services, at a fixed location. Member States should also have the possibility to ensure affordability of adequate broadband internet access and voice communication services other than at a fixed location to citizens on the move, where they consider that this is necessary to ensure consumers' full social and economic participation in society. Particular attention should be paid in this context to ensure that end-users with disabilities have equivalent access. There should be no limitations on the technical means by which the connection is provided, allowing for wired or wireless technologies, nor any limitations on the category of operators which provide part or all of universal service obligations."

It should be emphasised that under Polish conditions, in September 2018 the Minister of Digital Affairs submitted for public consultation a draft of the updated National Broadband Plan (hereinafter referred to as NBP), a Government development programme defining the objectives in the field of universal access to fast and very fast internet, as well as measures to implement these objectives. This draft specifies a number of key tasks, including:

1) ensuring universal access to internet connectivity of at least $100 \mathrm{Mbps}$ by 2025 , based on networks allowing the provision of services at bandwidths of several Gbps

2) ensuring access to internet connectivity of at least 1 Gbps by 2025 to locations which are the main drivers of socio-economic development (such as schools, healthcare institutions, public service locations, and transport nodes)

3) ensuring $5 \mathrm{G}$ network connectivity in at least 1 major city by 2020 , and in all major cities, and along the main railway and road lines, by 2025 .

The objectives specified in the updated NBP are consistent with the European objectives defined by the European Commission in its communication Connectivity for a Competitive Digital Single Market - Towards a European Gigabit Society 1, which is a continuation of the Community policy strategy in the field of access to fast internet specified in the European Digital Agenda.

On the basis of the foregoing assumptions, it is particularly important to define the tasks of public administration, especially local governments, as the part of social organisation whose direct purpose is to fulfil the basic needs of the individual. 


\subsection{The public tasks of local government units in the field of cybersecurity}

The public tasks aimed at ensuring the security of the cyberspace play an important role in the efficient functioning of the State. All network users are responsible for ensuring cybersecurity, but particular responsibility lies with public administration bodies, the main tasks of which include efforts to ensure public security and order. The expansion of advanced information and communication technologies made public administration responsible not only for the quality and maintenance of transport routes and the road network, but also for the communication routes of the ICT network. It should be added that polish definition of cybersecurity means the resistance of information systems to actions violating the confidentiality, integrity, availability and authenticity of the processed data or related services offered by these systems ( LAW of 5 July 2018 about the national cybersecurity system Dz.U.2020.1369). This is narrow definition related to definition of 'security of network and information systems' ( what means the ability of network and information systems to resist, at a given level of confidence, any action that compromises the availability, authenticity, integrity or confidentiality of stored or transmitted or processed data or the related services offered by, or accessible via, those network and information systems) (Directive (eu) 2016/1148 of the European Parliament and of the Council of 6 July 2016 concerning measures for a high common level of security of network and information systems across the Union OJ L 194, 19.7.2016, p. 1-30). Creating a technical infrastructure and a system of access to it for specific users requires substantial funds, which can be invested primarily by private entities interested in profit. According to Szydło (Szydło 2013, p. 3) "overcoming the identified barriers generally requires substantial financial resources, for which telecommunications enterprises are neither equipped nor willing to spend." As a result, "the role of the body to dismantle these barriers must be taken by public authorities acting in the general interest." It would seem that the consequent function of public administration should be only to provide security to ICT systems and networks, and to select the entities to ensure the continuity and high quality of services, while guaranteeing access to as large a group of recipients as possible (Dębicka 2008, p. 33). In Poland, as in other countries of the European Union, it has been accepted that the functions of new information and communication technologies should drive the social and economic development of a country, with a significant role being ascribed to transforming the activities of public administration so that they are based on friendly and transparent administrative structures. Local government administration clearly forms a certain separate organisational structure, which is made up of various units with the expertise specified in the Acts, and creating a specific organisational system to perform public tasks (cf. Lang 2014, p. 15). The tasks of a public administration in a democratic rule of law have the nature of legal obligations. They are specified by the Constitution and legal Acts formulated by 
the appropriate legislative bodies. Public administration bodies must not violate the constitutional rights and freedoms of citizens when carrying out their public tasks. It is indicated that the limits of actions taken by public authorities are outlined not only by substantive law, but especially the rights and freedoms of citizens safeguarded by the Constitution, and courts of law. In the rule of law, administrative functions must be clearly and directly specified in the Constitution, or be drawn from the constitutional norms describing the objectives and functions of the State, and the rights of its citizens, as formulated by indirect interpretation. A State performs its tasks through bodies of public authority. Public administration bodies, local government bodies, and other State entities are responsible for public tasks. This is provided for by acts of law and carried out in the public interest. Polish law does not have a legal definition of public tasks. However, they are postulated by numerous academic papers (Dębicka 2008, p. 33). Public administration is based on the carrying out of public tasks by public and private bodies, who are entrusted with public tasks (the privatisation of public-task implementation). The definition of public administration presented by Boć allows the deriving of the term of a public task - the tasks assumed by the State, involving meeting the collective and individual needs of people, arising from their coexistence in societies. The scope of the tasks assumed by the State is shifting in connection with the development of communities and the changing reality. These tasks are implemented on the basis of legal regulations (Boć 2004, p. 17). A similar view is presented by Biernat, according to whom "public tasks may be performed by public bodies with no executive authority, or even by non-public bodies. The main criterion for defining specific tasks as public is whether the State or local government is legally responsible for implementing them. Performing tasks as part of the organisational structures of the State or public government alone is not treated as a classification criterion for public tasks. If public tasks are entrusted to other bodies, they remain responsible for them, but the scope and forms of activity and responsibility change." (Biernat 1994, p. 23). Schmidt sees public tasks as "[...] a set of organisational and executive actions, activities, and projects conducted for the purposes of furthering public interest by various entities, bodies and institutions on the basis of acts of law and in the forms provided for by law" (Schmidt 2012, p. 137). Kocowski uses the term "public tasks" when referring to "[...] the legal responsibility to achieve or maintain a specific status-quo by an entity clearly specified in legal regulations, this status's being important and desirable in the context of the public interest" (Kocowski 2012, p. 48-49). These two definitions, although they differ in content, bear a lot of similarity. Public tasks involve the totality of tasks carried out by the State, which implements them by means of public administration. According to the applicable regulations, public tasks are carried out with the use of planned and rational tasks leading to a specific purpose (see Mikicka 2012, p. 407). According to Zimmermann, the basic criterion for considering a task "public" is whether the State or local government is legally responsible for implementing it (Zimmermann 2008, p. 261). These objectives are identified with the public interest (Zimmermann 2007, p. 95). 
However, according to Knosala, there are currently no clear criteria which would make it possible to differentiate between what is public and what is private. This means that defining a public task is not as clear-cut as it used to be (Knosala 2006, p. 77). Legal regulations constitute a legal basis for public administration and set the framework under which public tasks can be performed. The observance of the law follows the constitutional principle of legality (the rule of law) expressed in Article 7 of the Constitution of the Republic of Poland (The Constitution of the Republic of Poland of 2 April 1997, Journal of Laws of 1997, No. 78, item 483, as amended, hereinafter referred to as the Polish Constitution); "public tasks" is a legal term used in the Constitution - in Articles 15, 16, 163 and 164 - in the context of the participation of local government in exercising public authority as provided for in Articles 7 and 10 [...]. The Constitution divides public tasks (duties) into tasks contributing to "satisfying the needs of a self-governing community" and tasks guaranteed by the Constitution or Acts by other public authority bodies, including such that a statute may instruct units of local government to perform "if the fundamental needs of the State shall so require" (Martysz, Szpor, Wojsyk 2015, pp. 47-48). However, the scope of public tasks in the field of cybersecurity is much wider. Public tasks in this field facilitate satisfying collective needs, including those of specific populaces, such as local communities, and they are also a way to ensure their safety and public order. In this sense, providing internet access is one of the key tasks of local governments. However, it should be emphasised that, in its resolution of 27 October 1994, W 10/93 (OTK 1994, No. 2, item 46), the Polish Constitutional Tribunal (hereinafter referred to as CT) ruled that all tasks of local governments aimed at satisfying the collective needs of local and national communities should be considered public tasks. According to the CT, "both the commissioned and the own tasks of a local government are public tasks within the meaning of the applicable law." In its decision of 26 June 1992 III ARN $32 / 92$, the Supreme Court (hereinafter referred to as SC) stated that a local government performs all tasks in the field of public administration as its own or commissioned tasks. Defining a municipality's own tasks as public tasks is not, according to the $\mathrm{CT}$, in conflict with the undeniable fact that a municipality, as an entity managing municipal property, does so in a manner specific to fulfilling its own tasks. It should also be mentioned that the set of systems making up critical infrastructure, including ICT networks, is part of municipal property. The Act of 26 April 2007 on crisis management (consolidated text, Journal of Laws of 2017, item 209) grants local governments special functions in respect of cybersecurity. The responsible authorities with regard to this matter on behalf of the local government are the District Governor and the Head of the Municipality (Mayor). Entrusting management to a single-person entity allows faster decision-making than in the case of collegiate bodies, which is extremely important in the field of crisis management, as it directly affects safety. The dynamics of hazards and their effects leave no room for undue delay (M. Karpiuk 2019, p. 33-34). Pursuant to Article 3 (2) of the Act on crisis management, critical infrastructure should be understood as systems, and the integrated functional objects of which they are 
composed, including installations, devices, civil engineering structures and services, which key to the security of the State and its citizens, and aim at guaranteeing the effective functioning of public administration bodies, as well as institutions and entrepreneurs (Chałubińska-Jentkiewicz 2014, p. 56). For this reason, public tasks are generally assigned to public administration bodies; however, due to a number of factors, they can be carried out by the private sector, but always under the supervision of public authorities when they relate to cybersecurity. The issue of which tasks should be performed by public authorities exclusively through its bodies, and which can (or must) be entrusted to other entities within public administration (in this case, local governments), or performed by non-public entities, becomes a strategic decision.

\subsection{Telecommunications access}

As per the definition contained in Chapter 1, Article 2 of Directive 2002/19/EC of the European Parliament and of the Council of 7 March 2002 on access to, and interconnection of, electronic communications networks and associated facilities (Access Directive) Official Journal L 108, 24/04/2002 pp. 7-20), "access means the making available of facilities and/or services, to another undertaking, under defined conditions, on either an exclusive or non-exclusive basis, for the purpose of providing electronic communications services, " including information society services and content broadcasting services. "It covers, inter alia, access to network elements and associated facilities, which may involve the connection of equipment, by fixed or non-fixed means (in particular this includes access to the local loop and to facilities and services necessary to provide services over the local loop), access to physical infrastructure including buildings, ducts and masts; access to relevant software systems including operational support systems, access to number translation or systems offering equivalent functionality, access to fixed and mobile networks, in particular for roaming, access to conditional access systems for digital television services; access to virtual network services." In this wording of the definition, "access" is understood as the making available of network infrastructure, or services connected with the provision of transmission media, which may be used by another enterprise for (or for the purposes of) providing electronic connection services and, through them, offering end users content broadcasting services and information society services (Rogalski 2011, p. $3)$. The main category of entities authorised to use the so-called "communication access" as defined in the Act of 16 July 2004, Telecommunications Law (Journal of Laws of 2019, item 2460, hereinafter TL, work is currently underway on the implementation of the Directive (EU) 2018/1972), covering the use of network elements and associated facilities, are telecommunications enterprises. Another group involves "special users," i.e. Government administration units conducting telecommunications activities which are not economic activities, i.e. activities aimed at satisfying their own needs and connected with the scope of the performed tasks. Two basic types of enterprises can be distinguished - service providers, who 
are authorised to provide telecommunications services (Article 2 (27)(a) TL), and operators, who provide public telecommunications networks and associated facilities (Article 2 (27)(b) TL). The essential condition for attaining the status of a telecommunications enterprise is acquiring the right to conduct business activities. As telecommunications activities are regulated activities, another requirement is to obtain sectoral rights, which involves being entered into the register of telecommunications enterprises. Pursuant to the Act of 24 April 2009 amending the Act on Telecommunications Law and certain other Acts (Journal of Laws, No. 85, item 716), as per Article 10 (1), not only must domestic enterprises be entered into the register, but also telecommunications operators from other EU Member States, which allows them to conduct their activities according to the same rules as in their home countries. Article 56 of the TFEU prohibits restrictions on the freedom to provide services within the EU in respect of nationals of Member States who are established in a Member State other than that of persons for whom the services are intended. The agent conducting and managing the register of telecommunications enterprises is the President of the Office of Electronic Communications. Only pursuant to Article 26 (4) TL are EU operators who apply to obtain access not obliged to make entries in the register if they do not conduct telecommunications activities, i.e. do not provide services or operate a network in the Republic of Poland. Telecommunications activities are part of the own public utility tasks of a local government unit, which means that they are financed from the local government budget (Karpiuk, 2019 The activities of a local government, p. 42). Local government belongs to a special category of authorised entities in the field of telecommunications access, along with entities performing public utility functions, whose activities in telecommunications are not directly regulated by Telecommunications Law, but by the Act of 30 August 2019, amending the Act on assistance in the development of telecommunications services and networks and certain other Acts (Journal of Laws of 2019, item 1815). The main purpose of this Act was to ensure the development of telecommunications access, and specific actions were aimed at broadband access and eliminating digital exclusion. The concept of the Act on assistance in the development of telecommunications services and networks involved the implementation of several priorities, which included (1) Open access to land and buildings (right of way), including improving access to the land of local government units and the legal entities of local governments, including in particular public roads managed by such entities; improving access to private land by optimising the procedure for granting authorisations to install devices; improving access to buildings by assigning additional responsibilities to their owners and managers, and opening areas with disproportionate or inadequate restrictions and bans established by local plans for investments, as well as introducing limitations on the freedom of planning with regard to telecommunications infrastructure (2) An effective investment process involving the elimination of legal barriers; the shortening and harmonising of administrative procedures; adjusting procedures to the needs of telecommunications 
development, including releasing "low-impact telecommunications infrastructure" from the requirement to obtain a location permission from the municipal local government; and introducing special rules for locating regional broadband networks implemented by regional governments, or jointly acting local government units under the operational programmes co-financed by the EU. One of the objectives was to specify that investment projects in the field of telecommunications are public-purpose investments, regardless of the status of the entity taking up such activities (3) Open access to infrastructure and infrastructurerelated competition between operators of water, sewage, and power networks; telecommunications networks of other operators (according to shared use or service access rules), including networks located in buildings, and next to buildings and telecommunications networks, of public bodies, including of local governments. For this reason, it was assumed that the applied regulatory measures should be adjusted to the changing situation on the telecommunications market, and imposed under a regulatory cycle (Piątek 2004, p. 161). The need to activate local governments was adopted as the fourth priority. In this respect, it is especially worth looking at the French solutions, which became the basis for the Polish legislator. An active local government plays a key role in these solutions. In accordance with the December 2008 report entitled "The first summary of localgovernment interventions in the electronic communications sector", the main purpose of public projects was to provide competitive services to consumers and local enterprises, and to ensure that digitally excluded households receive access to broadband internet. The impact of local government interventions on each of the said items was significant, as

- nearly $40 \%$ of telephone exchanges were decoupled, making up 4.6 million lines. Two million lines would have never been released without public intervention. For the remaining 2.6 million lines, public intervention led to faster decoupling than in the case of private intervention. Through this, local governments contributed to improving the disadvantageous situation caused by French geography, and strengthening France's position among the European leaders in broadband access.

- nearly 2000 economic zones have fibre-optic connections thanks to public initiative networks.

- networks aimed at eliminating areas not covered by broadband internet (blank spots) cover $80 \%$ of the population in such areas. On a national scale, the local governments involved in programmes aimed at eliminating blank spots represent nearly half the population of the areas without broadband coverage. 
The main objectives of the said Act included introducing a clear legal basis for local government units to carry out tasks in the field of telecommunications; determining the basic principles of intervention by local government units on the local telecommunications market, without distorting competition, and increasing the effectiveness of procedures for joint task implementation in the field of telecommunications by local government units and entrepreneurs (concessions for construction works and services, public procurement, public-private partnerships, and making available assets, particularly technological channels).

This is clearly an own public-utility task of a local government unit. Local governments carry out their own tasks on behalf of the State, in their own names, and to satisfy the needs of individuals making up a given community (cf. Kasina, 2019, p. 15).

The telecommunications-related tasks of local government units are provided for in Article 3 (1) of the Act on assistance. The legislator divided these into three groups. A local government unit may build and use telecommunications infrastructure (e.g. cable ducting, poles, and other accessories - Article 2 (8) of the Act of 16 July 2004 on Telecommunications Law 5; this refers to items which are the material basis for telecommunications networks, and telecommunications networks (i.e. all resources allowing the broadcast, receipt, or transmission of signals - Article (2)(35) TL), and acquire the rights to infrastructure and networks; provide telecommunications networks (i.e. prepare the telecommunications network in a way making it possible to provide services - Article 2 (4) TL), or provide access to telecommunications infrastructure (which is one of the aspects of telecommunications access, i.e. making use of somebody else's telecommunications devices to provide your own services - Article 2 (6) TL), and provide, using the infrastructure and network held, services for 1) telecommunications enterprises 2) public bodies and organisational units as listed in Article $4(1,2,4,5$ and 8$)$ TL (the purpose of providing services in this case is to satisfy the said entities' own needs) 3 ) end users (i.e. entities using publicly available telecommunications services to meet their own needs - Article 2 (50) TL.; these involve, i.a., members of households, but also entrepreneurs other than those providing telecommunications services).

\section{$4 \quad$ Discussion}

\subsection{The procedure for the provision of telecommunications access by local government units}

Local government units are obliged to grant justified requests filed by telecommunications enterprises, the entities referred to in Article 4(1), 2, 4, 5, and 8 of the Telecommunications Law of 16 July 2004, and by other local government units seeking telecommunications access, including the use of network elements 
and associated facilities. Telecommunications access is governed by the respective provisions of Part II Chapter 2 of the Telecommunications Law of 16 July 2004 (on telecommunications access), whereby a local government unit performing the activities referred to in Article 3(1) of the said Act is obliged to enter into a telecommunications-access agreement within 30 days of the date of the application for entering into such an agreement, and to exercise equal treatment towards telecommunications enterprises by proposing the same conditions in comparable circumstances. The provisions of Part I Chapter 3 of the Telecommunications Laws are also applied to decisions on telecommunications access under which, i.a., consultation proceedings are regulated.

If a given telecommunications enterprise is granted telecommunications access, in particular access to telecommunications devices, telecommunications buildings and infrastructure, or the facility to share telecommunications buildings and infrastructure with another entity, regulatory obligations imposed on such telecommunications enterprise are applied to the same extent and under the same conditions to devices, buildings, infrastructure, facilities, services, and other elements covered by telecommunications access or shared use. This relates to telecommunications enterprises which have been granted telecommunications access, or the facility to share telecommunications buildings and infrastructure, by a local government unit, or an entity which has entered into a concession contract with a local government unit, within the meaning of the Act of 21 October 2016 on the concession contract for works or services (Journal of Laws of 2019, No. 1528), or a public-private partnership contract within the meaning of the Act of 19 December 2008 on public-private partnership (Journal of Laws of 2020, No. 711) in the field of telecommunications buildings and infrastructure covered by telecommunications access or shared use. This means that these obligations are related to the use of public property which can also be in the hands of privatesector representatives who perform public tasks. The first issue refers to defining the basic framework for activities in the telecommunications sector in the field of interventions on the supply side. The objective of the aforementioned provision related to access was to create the most comprehensive framework possible for such activities, which would include diverse projects, and would not restrict the proactive approach of local government units, at the same time establishing statutory and institutional guarantees, and preventing the distortion of competition in the telecommunications sector. The principal types of permissible activities on the supply side should be identified for the telecommunications sector. Such activities primarily involve the development of telecommunications infrastructure and its preparation for use as the base layer of the telecommunications network. It is also allowed to develop telecommunications networks, operate such networks and infrastructure, and acquire rights to the existing infrastructure. A local government unit which is the holder of a network may also perform activities in the field of providing access to such an infrastructure and network to telecommunications enterprises and holders of networks other than private 
networks, while the most advanced form of such access is the provision of wholesale telecommunications services.

Moreover, the amendment of Article 3 of the Act of 7 May 2010 on Support for the development of telecommunications services and networks, by adding Paragraph 1a, was aimed at introducing a ban on the duplicating of telecommunications infrastructure or networks by local government units, except where telecommunications infrastructure (or telecommunications networks) do not exist in a given area, and where it is not possible to use the existing telecommunications infrastructure, because it is unavailable, or does not meet the local government's requirements. Under the legal regulations in force, such activities should be performed with a view to catering for the collective needs of local communities, and should be pursued in a way which does not disrupt the development of fair and effective competition on telecommunications markets. However, it is still possible for local government units to run operations in the field of developing telecommunications infrastructure and networks (which are not part of such local government's core activities) which in individual instances can compete against the investment projects of telecommunications enterprises for whom the development of telecommunications infrastructure and networks constitutes part of their core business activities. By introducing the said restrictions, the rights of local government units to conduct activities in the field of telecommunications, entailing the development of telecommunications infrastructure and networks, were specified in greater detail.

Local government units may commission services using strategic networks to private entities, for example under a concession contract. Such conditions create basic guarantees that the activities of local government units as part of performing their tasks will not distort competition in the telecommunications sector, or will not limit, but foster, private investment initiatives. The infrastructure and networks developed or acquired by local government units are subject to the "open access" principle, which means that such units are obliged to allow the shared use or access to interested telecommunications enterprises on fair and transparent terms (while meeting the requirements related to state security and defence needs). The "open access" principle is recommended by the European Commission (Cf.: Guidelines on Criteria and Modalities of Implementation of Structural Funds in Support of Electronic Communications, SEC(2003)895), and any exceptions to the principle require special substantiation. In such an event, the general rules which govern the availability of infrastructure provided by telecommunications enterprises are applied as defined in Telecommunications Law. Moreover, the President of the Office of Electronic Communications was granted authority to resolve any disputes in this area, and to define the terms and conditions of cooperation.

Different legal solutions were developed for the access to the technical infrastructure owned by a local government unit (defined as public technical 
infrastructure) by introducing free access to such an infrastructure to place smallarea wireless access points. Therefore, under Article 17a of the Act on Support, access to the technical infrastructure owned by local government units, and national or local government organisational units, is free-of-charge. The Act also regulates the principles of access to technical infrastructure, including the access to information about the infrastructure. Making the network available to further entities is a separate issue. Under Article 19(4) of the Act on Support, network operators may refuse access to technical infrastructure to a telecommunications enterprise if:

1) it is not possible for technical reasons to place elements of telecommunications networks in the technical infrastructure covered by a given application

2) there is no sufficient space available to place the elements of a telecommunications network, taking into considerations the future demand of a network operator for space in the technical infrastructure covered by such an application, arising from the network operator's schedule of planned investment projects covering the remaining space in the technical infrastructure

3) the use of technical infrastructure is not possible because of public safety, public health, or network integrity and security, including in particular critical infrastructure

4) the planned telecommunications services might cause serious disruptions in providing other services via the same technical infrastructure

5) it provides the telecommunications enterprise with effective access to technical infrastructure which is other than that indicated in the relevant application, and which:

a) meets the needs of such a telecommunications enterprise in the field of high-speed telecommunications networks

b) is provided under terms which do not distort fair competition.

According to Dziomdziora "the above premises, in particular those indicated in Points 1-4, are highly evaluative. Therefore, disputes between networks operators and telecommunications enterprises interested in gaining access are possible in matters concerning the question of whether a given circumstance has occurred or not. Moreover, if any of the aforementioned circumstances occur, such operator may, but is not obliged to, refuse access. It seems that such a solution is not correct. For instance, if access to technical infrastructure would involve a threat to state security, or result in serious disruptions in rendering other services via the same technical infrastructure, such a refusal should be mandatory, not optional" (Dziomdziora 2016, p. 144).

The provision of universal wireless electronic communication, facilitating the implementation and operation of technological solutions which form part of smart cities or autonomous mobility, very often involves the use of a substantial number 
of small-area wireless access points. An obvious and non-invasive solution is to use for this type of installations the existing "municipal" infrastructure, such as poles, street lamps, and bus shelters. Such a solution is consistent with the provisions laid down in the Directive establishing the European Electronic Communications Code (Articles 57(4) and 57(5)), under which "Member States shall, by applying, where relevant, the procedures adopted in accordance with Directive 2014/61/EU, ensure that operators have the right to access any physical infrastructure controlled by national, regional or local public authorities, which is technically suitable to host small-area wireless access points or which is necessary to connect such access points to a backbone network, including street furniture, such as light poles, street signs, traffic lights, billboards, bus and tramway stops and metro stations. Public authorities shall meet all reasonable requests for access on fair, reasonable, transparent and non-discriminatory terms and conditions, which shall be made public at a single information point" (paragraph 4), and "without prejudice to any commercial agreements, the deployment of small-area wireless access points shall not be subject to any fees or charges going beyond the administrative charges in accordance with Article 16" (paragraph 5). Here, it is also worth referring not only to the provisions of Article 57(4) and (5) of the European Electronic Communications Code, but also to the contents of recital 140 of the Directive, which states "public buildings and other public infrastructure are visited and used daily by a significant number of endusers who need connectivity to consume eGovernment, eTransport and other services. Other public infrastructure, such as street lamps, traffic lights, offer very valuable sites for deploying small cells, for instance, due to their density. Without prejudice to the possibility for competent authorities to subject the deployment of small-area wireless access points to individual prior permits, operators should have the right to access to those public sites for the purpose of adequately serving demand. Member States should therefore ensure that such public buildings and other public infrastructure are made available on reasonable conditions for the deployment of small-cells with a view to complementing Directive 2014/61/EU and without prejudice to the principles set out in this Directive". It should also be noted that the provisions of the European Electronic Communications Code were to be implemented in domestic legislations within two years of entering into force, i.e. by 20 December 2018 .

\section{6}

\section{Financial aid}

The second issue which is significant from the perspective of public tasks performed by local government units in the field of telecommunications is the issue of state aid. Article 15 of the aforementioned Act on Support introduced laws referring to the activities of local government units to encourage demand for services related to Internet access. Local government units may conduct activities aimed at fostering or aggregating users' demand for services related to broadband Internet access, including, in particular, educational and training requirements, 
which involves providing consumers with telecommunications terminal equipment or computer equipment, or financing the costs of telecommunications services. Decision-making bodies of local government units define, by way of a resolution, the conditions and procedures for financing activities, in particular defining the eligibility criteria applicable to aid beneficiaries. Such activities should be performed in a non-discriminating manner, in line with transparency and proportionality principles, and with a view to retaining technological neutrality. Furthermore, each such undertaking of local government units, falling within the scope of their operations, requires a pre-announcement, together with a description, in the Public Information Bulletin on the website of such a local government unit, and at its premises. Therefore, the permissibility of a local government unit's intervention should be ultimately tested against the requirements laid down in the legal regulations governing state aid, which are aimed at, i.a., limiting such interventions to situations in which private initiatives are insufficient, and the distortion of competition on a given market is limited to a minimum. The adopted solution arises directly from the contents of the Communication from the Commission - Community Guidelines for the application of State-aid rules in relation to the rapid deployment of broadband networks (OJ C 235, 30.09.2009, p. 7-25), and is aimed at ensuring that competition will not be distorted on a given market. In accordance with Point 5 of the said Guidelines "at the same time, it must be ensured that State aid does not crowd out market initiative in the broadband sector. If State aid for broadband were to be used in areas where market operators would normally choose to invest, or have already invested, this could affect the investments already made by broadband operators on market terms, and might significantly undermine the incentives of market operators to invest in broadband in the first place. In such cases, State aid to broadband might become counterproductive to the objective pursued. The primary objective of State-aid control in the field of broadband is to ensure that State-aid measures will result in a higher level of broadband coverage and penetration, or at a faster rate, than would occur without the aid, and to ensure that the positive effects of aid outweigh its negative effects in terms of distortion of competition." Under Article 3a of the Act on Support, local governments may grant special-purpose subsidies to finance development project costs, in particular the telecommunications connection from a land plot boundary to a building.

\section{$7 \quad$ Conclusions}

In the current legal conditions, local government units have become public trust institutions to end users, which results in the fact that an increasing number of users might decide to enter into contractual relationships as part of programmes implemented by local government units. At the same time, such operations should be transparent, proportional, non-discriminating, and be aimed at retaining technological neutrality and accounting separation in the field of tasks related to 
support programmes. The principle of proportionality is one of the most fundamental principles expressed in Article 5 of the Treaty on European Union. It means that any measures taken within such operations must be appropriate to the tasks assigned. According to this principle, activities should be suitable for attaining the objective pursued, and necessary and proportional in the strict sense of the word (must interfere to the smallest extent possible with attaining any other objectives). In turn, conceptualising the "right to Internet access" helps to define it precisely within the vertical arrangement, i.e. in the relationship between the citizen and the state, and identify the scope of responsibility of the state towards eligible persons. The right of an individual to use Internet access without interference from third-parties should be differentiated from the State's obligation to provide access to ICT networks. Although the provisions of international law seem to be the appropriate platform for acknowledging the right to Internet access, the right to access state-of-the-art digital services does not require the application of universally (globally) accepted measures, and can be effectively exercised with the use of domestic, local, or regional solutions, as in the case of obligations placed on local government units in the field of telecommunications access.

\section{Acknowledgment:}

This article has been prepared in the result of cooperation at the realization of the research project, entitled "The Polish cybersecurity system - a model of legal solutions" The Agreement MON Nr GB/4/2018/208/2018/DA] granted by Ministry of National Defence

\section{References:}

Babis H. (ed.) (2011), Flaga-Gieruszyńska K. (ed.) Rynek usług telekomunikacyjnych [The telecommunications services market] (Warsaw: Wydawnictwo Wolters Kluwer).

Boć J. (ed.) (2007) Prawo administracyjne [Administrative Law] (Wrocław: Wydawnictwo Kolonia Limited).

Chałubińska-Jentkiewicz K. (2014) Bezpieczeństwo cyberprzestrzeni jako zadanie publiczne w systemie bezpieczeństwa narodowego RP, Zeszyty Naukowe AON, 3(2), pp. 20-35.

Czuryk, M. (2019) Wspieranie rozwoju usług i sieci telekomunikacyjnych za pośrednictwem jednostek samorządu terytorialnego oraz cyberbezpieczeństwo, [Supporting the development of telecommunications services and networks through local and regional government bodies, and cybersecurity], Cybersecurity \& Law, 2, pp. 39-51.

Dobkowski J. (2004) Struktura interesu publicznego a zasady rozdzielenia odpowiedzialności publicznoprawnej w Administracji [The public interest structure and the principles of dividing public law responsibility in administration], In: Jednostka państwo - Administracja. Nowy wymiar [The Individual - the State - Administration. A New Dimension] (Rzeszów: Wydawnictwo "Mitel" Rzeszów).

Dziomdziora W. (2016) Kierunki zmian ustawy o wspieraniu rozwoju usług i sieci telekomunikacyjny [Directions of amendments to the Act on support for the development of telecommunications services and networks], Internetowy Kwartalnik Antymonopolowy i Regulacyjny, 5(6), pp. 111-119. 
Galewska, E.(2015) Obowiązek zawarcia umowy o połaczeniu sieci telekomunikacyjnych [The obligation to enter into an agreement on the interconnection of telecommunications networks] (Warsaw: Wydawnictwo: Wolters Kluwer).

Jaxa Dębicka, A. ( 2008) Sprawne państwo [An Efficient State] (Warsaw: Wydawnictwo Wolters Kluwer).

Karpiuk, M. (2014) Miejsce samorzadu terytorialnego $w$ przestrzeni bezpieczeństwa narodowego (Warsaw: Wydawnictwo AON).

Karpiuk, M. (2019) Activities of the local government units in the scope of telecommunication, Cybersecurity and Law, 1, pp. 37-48.

Karpiuk, M. (2019) Position of the Local Government of Commune Level in the Space of Security and Public Order, Studia Iuridica Lublinensia, 28(2), pp. 27-39, https://doi.org/10.17951/sil.2019.28.2.27-39.

Karpiuk, M. \& Kostrubiec, J. (2018) The Voivodeship Governor's Role in Health Safety, Studia Iuridica Lublinensia, 27(2), pp. 65-75, https://doi.org/10.17951/si1.2018.27.2.65.

Kasina, K. S. (2019) Działalność jednostek samorządu terytorialnego w zakresie telekomunikacji niebędąca działalnością gospodarczą [The activities of local government units in the field of telecommunications other than business activities], Samorzad Terytorialny, 1-2, pp. 15-25.

Knosala E. (2006) Zarys nauki administracji [An Introduction to Administration Studies] (Zakamycze: Wydawnictwo Wolters Kluwer).

Kocowski T. (2012) Prywatyzacja zarządzania majątkiem publicznym, prywatyzacja majątkowa, prywatyzacja zadań publicznych i prywatyzacja wykonania zadań publicznych [The privatisation of public property management, the privatisation of assets, the privatisation of public tasks, and the privatisation of public task performance], In: Blicharz, J. (ed.) Prawne aspekty prywatyzacji [The legal aspects of privatisation] (Wrocław: Wydawnictwo Prawnicza i Ekonomiczna Biblioteka Cyfrowa).

Lang, J. (2014) Zagadnienia wstępne [Introductory issues], In: Wierzbowski, M. (ed.) Prawo administracyjne [Administrative Law] (Warsaw: Wydawnictwo Lexis Nexis).

Martysz, Cz., Szpor, G. \& Wojsyk, K. (2015) Ustawa o informatyzacji działalności podmiotów realizujacych zadania publiczne. Komentarz, wyd. II [The Act on computerising the activities of entities performing public tasks. A commentary, 2nd Edition] (Warsaw: Wydawnictwo Lex 10190).

Mikicka, A. K. (2012) Partnerstwo publiczno-prywatne jako prywatyzacja sensu largo zadań publicznych jednostek samorządu terytorialnego [Public-private partnership as sensu largo privatisation of public tasks performed by local government units], In: Blicharz,J. (ed.) Prawne aspekty prywatyzacji [The legal aspects of privatisation] (Wrocław Wydawnictwo Prawnicza i Ekonomiczna Biblioteka Cyfrowa).

Piątek, S. (2004) Regulacja na rzecz konkurencji w sektorze telekomunikacyjnym [Laws governing competition in the telecommunciations sector], problemy Zarzadznia, 2(3), pp. $16-25$.

Rogalski, M. (ed.) (2013) Prawo telekomunikacyjne. Komentarz, [Telecommunications Law. A Commentary] (Warsaw: Wydawnictwo Wolters Kluwer).

Schmidt, P. (2012) Prywatyzacja zadań publicznych w zakresie zapewnienia dostępu do kultury [The privatisation of public tasks in terms of access to culture], In: Blicharz, J. (ed.) Prawne aspekty prywatyzacji [The legal aspects of privatisation] (Wrocław: Wydawnictwo Prawnicza i Ekonomiczna Biblioteka Cyfrowa).

Szydło, M. (2013) Introduction to the Act, In: Grossmann, T., Knopkiewicz, W., SebzdaZałuska, J., Szydło, M., Wilczewski, J. (eds.) Ustawa o wspieraniu rozwoju [The Act on Support for Development] (Warszawa: Wydawnictwo: C.H. Beck). 
Zimmermann, J. (2008) Prawo administracyjne [Administrative Law] (Warszawa: Wydawnictwo Wolters Kluwer).

Zimmermann, J. (ed.) (2007) Cele publiczne i zadania publiczne, Koncepcja systemu prawa administracyjnego [Public objectives and public tasks. The concept of the administrativelaw system] (Warsaw: Wydawnictwo Wolters Kluwer).

\section{Case law:}

Resolution of the Constitutional Tribunal of 27 October 1994, W 10/93 (OTK 1994, No. 2, Item 46).

Decision of the Supreme Court of 26 June 1992, III ARN 32/92 (LEX nr 1633100). 